Original paper

\title{
Octahedral substitution in beryl from weakly fractionated intragranitic pegmatite Predné Solisko, Tatry Mountains (Slovakia): the indicator of genetic conditions
}

\author{
Peter BAČÍK ${ }^{1,2, *}$, Jana FRIDRICHOVÁ1, Pavel UHER¹, Samuel RYBÁR ${ }^{3}$, Valéria BIZOVSKÁ4, \\ Jarmila LUPTÁKOVÁ5, Dana VRÁBLIKOVÁ, Libor PUKANČÍK ${ }^{7}$ Tomáš VACULOVIČ8 \\ ${ }^{1}$ Department of Mineralogy and Petrology, Faculty of Natural Sciences, Comenius University, Ilkovičova 6, 84215 Bratislava, Slovakia; \\ peter.bacik@uniba.sk \\ 2 Earth Science Institute of the Slovak Academy of Sciences, Dúbravská cesta 9, 84005 Bratislava, Slovak Republic \\ ${ }^{3}$ Comenius University in Bratislava, Faculty of Natural Sciences, Department of Geology and Paleontology, Ilkovičova 6, 842 15 \\ Bratislava, Slovakia \\ ${ }^{4}$ Slovak Academy of Sciences, Institute of Inorganic Chemistry, Dúbravská cesta 9, 84536 Bratislava, Slovakia \\ ${ }^{5}$ Earth Science Institute of the Slovak Academy of Science, Dumbierska 1, 97401 Banská Bystrica, Slovakia \\ ${ }^{6}$ Water Research Institute, Nábrežie arm. gen. L. Svobodu 5, 81249 Bratislava, Slovakia \\ ${ }^{7}$ Hornonitrianske bane Prievidza, a.s. Ťažobný úsek Čáry, Čáry 303, 90843 Čáry, Slovakia \\ ${ }^{8}$ Central European Institute of Technology, Masaryk University, Kamenice 5, 62500 Brno, Czech Republic \\ * Corresponding author
}

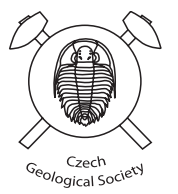

Crystal-chemical properties, and octahedral substitution role in particular, of beryl from weakly fractionated intragranitic pegmatite at Predné Solisko, Vysoké Tatry Mts. (Slovakia) is described in detail. The studied beryl was found in granitic pegmatite derived from biotite $\mathrm{I}$-type granodiorite. It has a weakly zoned core with variable $\mathrm{Fe}$ and $\mathrm{Mg}$ contents but constantly high Na. The rim zone shows weak irregular chemical zoning with low $\mathrm{Na}$ and $\mathrm{Mg}$, the latter dominating over Fe. The total $\mathrm{Al}$ content varies between 1.77 and $1.87 \mathrm{apfu}$; $\mathrm{Al}$ is substituted by $\mathrm{Fe}$ (0.03-0.07 apfu) and mostly by $\mathrm{Mg}(0.02-0.13 \mathrm{apfu})$. The decrease in octahedral site charge is mostly balanced by $\mathrm{Na}(0.05-0.30 \mathrm{apfu})$. However, the $\mathrm{Na}$ content in the rim is insufficient for balancing octahedral $\mathrm{Fe}+\mathrm{Mg}$, implying that at least a part of Fe is ferric. The c/a ratio is typical of "normal" beryl but its low value suggests dominant octahedral substitution. The $2 b$ channel site is occupied by Na, Ca, REE and Sr. At the larger $2 a$ site, Cs is clearly the most abundant (up to $3919 \mathrm{ppm}$ ). Water is present as both type I and type II but with large dominance of doubly coordinating $\mathrm{H}_{2} \mathrm{O}$ type II suggesting relatively fluid-rich genetic environment. The composition of beryl reflects the source rock of pegmatitic melt; I-type granitoids are generally enriched in $\mathrm{Mg}$ compared to $S$-type ones and consequently, the ${ }^{C} \mathrm{Na}^{\circ} \mathrm{Mg}^{\mathrm{C}} \square_{-1}{ }^{\mathrm{O}} \mathrm{Al}{ }_{-1}$ substitution may play a more important role in beryl from I-type derived pegmatites such as Predné Solisko. The geological position of the studied intragranitic pegmatite excludes the possibility of contamination from the host rock and the beryl chemistry, therefore, reflects faithfully the pegmatitic melt composition.

Keywords: beryl, crystal chemistry, octahedral substitution, site occupancy, intragranitic pegmatite, High Tatras Received: 10 May 2018; accepted: 7 November 2018; handling editor: M. Novák

\section{Introduction}

Beryl is the most widespread beryllium mineral in rareelement, beryl and complex type of the LCT ( $\mathrm{Li}-\mathrm{Cs}-\mathrm{Ta})$ suite and, less frequently, in the NYF (Nb-Y-F) suite of granitic rare-element pegmatites (Černý and Ercit 2005). Beryl is the first rare-element mineral to crystallise in the evolutionary sequence of the LCT pegmatites and it is a characteristic phase in the relatively less fractionated granitic pegmatites of the beryl-columbite subtype. The latter subtype normally lacks $\mathrm{Li}$ and $\mathrm{Cs}$ minerals but commonly occurs with $\mathrm{Nb}$-Ta oxide minerals, especially with columbite group members (Černý 2002; London and Evensen 2002; London 2008). These pegmatite popula- tions are usually closely connected with their parental granitic rocks; the pegmatite dikes are situated directly in the granites or in the metamorphic country rocks, near the granite exocontact.

Beryl chemistry results from heterovalent substitutions at octahedral and tetrahedral sites (e.g., Wood and Nassau 1968; Aurisicchio et al. 1988). These substitutions influence the lattice parameters which allows the definition of three beryl series on the basis of the c/a ratio: (1) the "octahedral" beryls, in which $\mathrm{Al} \leftrightarrow \mathrm{Me}^{2+}$ represents the main isomorphous replacement $(c / a=$ 0.991-0.996); (2) the "tetrahedral" beryls, where Be $\leftrightarrow \mathrm{Li}$ is the main substitution $(c / a=0.999-1.003)$ and (3) the "normal" beryls where the two substitutions occur 


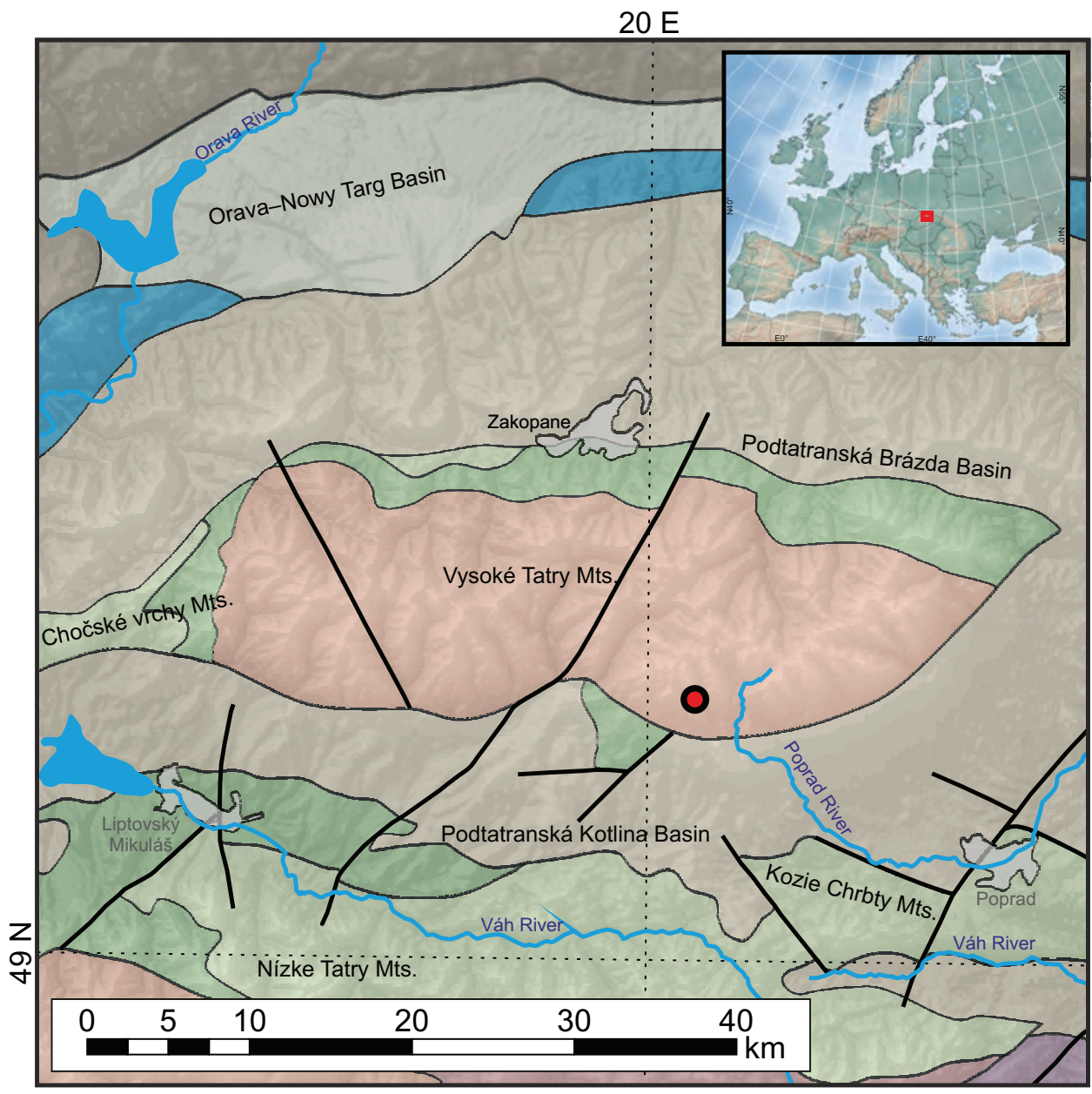

\section{Neogene \& Quaternary \\ Orava-Nowy \\ Targ Basin \\ Paleogene}

Sediments of the Inner Carpathian

Paleogene Basin

Paleogene \& Mesozoic

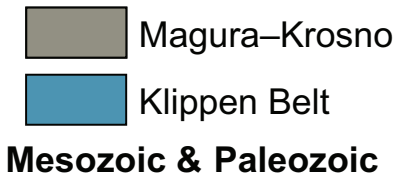

Mesozoic \& Paleozoic

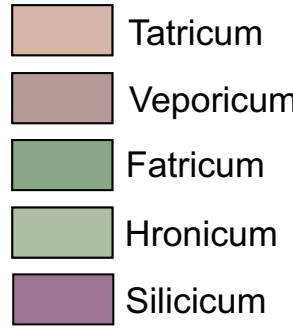

Digital elevation

model (m.a.s.l.)

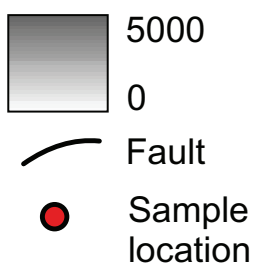

Fig. 1 Simplified geological map of Vysoké Tatry Mts. (adapted after Hók et al. 2014).

together, though to a limited extent $(c / a=0.997-0.998)$ (Aurisicchio et al. 1988).

Beryl composition influenced by the main substitutions is a sensitive indicator of the pegmatite environment and fractionation degree (Černý 2002; Simmons 2007; Turner et al. 2007; Groat et al. 2010; Novák and Filip 2010; Aurisicchio et al. 2012). Tetrahedral substitution is typical of beryl from fractionated Li,Cs-rich granitic pegmatites (Aurisicchio et al. 1988, 2012; Černý 2002; Simmons 2007; Turner et al. 2007). Beryl from relatively less fractionated Li,Cs-poor granitic pegmatites is more influenced by the octahedral substitution (Aurisicchio et al. 1988; Černý 2002; Uher et al. 2010). This Fe and Mg enrichment in beryl is usually connected with weaker fractionation or contamination of granitic pegmatites (e.g., Schaller et al. 1962; Aurisicchio et al. 1988, 2012; Uher and Broska 1995; Černý 2002; Černý et al. 2003; Wang et al. 2009; Beal and Lentz 2010; Novák and Filip 2010; Uher et al. 2010; Aurisicchio et al. 2012; Přikryl et al. 2014). However, the crystal-chemistry of Fe,Mgenriched beryl from primitive, weakly fractionated pegmatites has been studied rather scarcely (e.g., Schaller et al. 1962; Aurisicchio et al. 1988, 2012; Novák and Filip 2010; Uher et al. 2010).

The aim of this study is a detailed description of crystalchemical and genetic properties of beryl from weakly fractionated pegmatite of Predné Solisko, Vysoké Tatry Mts. (Slovakia) and determination of octahedral substitution role in beryl. Beryl chemical composition will be determined by combining electron-microprobe analysis (EMPA) and laserablation inductively-coupled plasma mass-spectrometry (LA-ICP-MS), structural properties by powder X-ray diffraction (XRD), water behaviour by Fourier-transform infrared (FTIR) and Raman spectroscopy. Based on the analytical data, we determine and interpret the influence of structural properties and genetic conditions on the range of octahedral substitution during beryl crystallisation.

\section{Geological setting of the beryl occurrence}

The Tatra Mts. are composed of Paleozoic metamorphic and granitic rocks overlain by sedimentary rocks of Mesozoic 
and Cenozoic age. While metamorphic rocks are abundant in the western part of the Tatry Mts. (Západné Tatry Mts.), they form only xenoliths in I- or mixed I/S-type granitoids in the easterly High Tatras (Vysoké Tatry Mts.) (Petrík et al. 1994; Broska and Uher 2001; Gawęda et al. 2016). Granitic and metamorphic rocks form the crystalline basement of the Tatric Unit of the Inner Western Carpathians and the granitic rocks are cut by numerous pegmatite, aplite and quartz veins (Andrusov 1968; Mahel' 1986; Hók et al. 2014).

The lower intercept $\mathrm{U}-\mathrm{Pb}$ zircon dating indicates that the youngest magmatic age should be $314 \pm 4 \mathrm{Ma}$, with melting and migmatization at $332 \pm 5$ Ma (Poller and Todt 2000; Poller et al. 2000). The ${ }^{40} \mathrm{Ar} /{ }^{39} \mathrm{Ar}$ laser-probe biotite dating yielded cooling ages of 300-330 Ma (Janák 1994; Kohút and Sherlock 2003). Furthermore, apatite and zircon fission-track data document that complex Alpine tectonic reorganisation and gradual uplift occurred between 95 and $7 \mathrm{Ma}$ (Králiková et al. 2014). During the Miocene, the area was affected by strong deformation (Plašienka 1999; Pešková et al. 2009).

Beryl has been described in rare-element granitic pegmatites from several mountain regions in the Tatric Unit of the Western Carpathians: Žiar Mts. (Fiala 1931), the Bratislava granitic Massif of Malé Karpaty Mts. (Gargulák and Vanek 1989; Uher 1994; Uher and Broska 1995; Ozdín 2010; Uher et al. 2010; Fridrichová et al. 2016), the Bojná granitic Massif of Považský Inovec Mts. (Uher 1991, 1992; Uher and Broska 1995; Uher et al. 2010), and the Prašivá intrusion in the Low Tatra Mts. (Pitoňák and Janák 1983; Uher 1992; Uher and Benko 1997). Beryl of the West-Carpathian pegmatites occurs usually in a quartz core or in coarse to blocky quartz $+\mathrm{K}$-feldspar (rarely albite) + muscovite unit, rarely in fine-grained saccharoidal albite (Uher et al. 2010; Ozdín 2010). Černý and Ercit (2005) classification assigns the West-Carpathian pegmatites to a beryl type, a beryl-columbite subtype and LCT family. They lack essential Li and Cs minerals, but are relatively rich in $\mathrm{Na}, \mathrm{Mg}$ and Fe, and this is reflected in their beryl compositions.

The beryl studied herein was the first discovered in the High Tatras Mountains; a completely new pegmatite locality. The described beryl-bearing granitic pegmatite (Fig. 1) is situated between the Pod Soliskom cottage and Predné Solisko Peak (2093 m a.s.l.), approximately 250 m SSE of the Peak, near Štrbské Pleso settlement. The pegmatite dike GPS coordinates are: N 498'48.86", E 20²'24.91".

\section{Experimental and analytical methods}

\subsection{Electron-microprobe analysis (EMPA)}

The chemical composition of beryl and associated minerals was established using a CAMECA SX100 electron microprobe at the State Geological Institute of Dionýz Štúr, Bratislava. The measurements were carried out in wavelength-dispersion mode, under the following conditions: accelerating voltage $15 \mathrm{kV}$, beam current $20 \mathrm{nA}$, and beam diameter $5 \mu \mathrm{m}$. The samples were analyzed with the following standards: wollastonite (Si $K_{\alpha}$, Ca $\left.K_{\alpha}\right), \mathrm{TiO}_{2}\left(\mathrm{Ti} K_{\alpha}\right), \mathrm{Al}_{2} \mathrm{O}_{3}\left(\mathrm{Al} K_{\alpha}\right)$, pure $\mathrm{Cr}\left(\mathrm{Cr} K_{\alpha}\right)$, fayalite (Fe $K_{\alpha}$ ), rhodonite $\left(\mathrm{Mn} K_{\alpha}\right)$, $\mathrm{MgO}\left(\mathrm{Mg} K_{\alpha}\right)$, pure $\mathrm{Ni}(\mathrm{Ni}$ $\left.K_{\alpha}\right)$, pure Zn $\left(\mathrm{Zn} K_{\alpha}\right)$, albite (Na $\left.K_{\alpha}\right)$, orthoclase $\left(\mathrm{K} K_{\alpha}\right)$, $\mathrm{Rb}_{2} \mathrm{ZnSi}_{5} \mathrm{O}_{12}$ glass $\left(\mathrm{Rb} L_{\alpha}\right.$ ) and pollucite (Cs $L_{\alpha}$ ). The measured elements detection limits ranged from 0.01 to 0.05 wt. \%; V, Zn, Sr, Rb and Cs were below detection limits in all analyses. The beryl crystal-chemical formula was then calculated on the basis of $8 \mathrm{O}+T$ cations and $\mathrm{BeO}$ of $3.00 \mathrm{apfu}$ (atoms per formula unit).

\subsection{Laser Ablation-Inductively Coupled Plasma-Mass Spectrometry (LA-ICP-MS)}

The LA-ICP-MS apparatus at the Department of Chemistry, Masaryk University, Brno, consists of a UP 213 laser-ablation system (New Wave Research, Inc., Fremont, USA) and Agilent 7500 CE ICP-MS spectrometer (Agilent Technologies, Santa Clara, USA). A commercial Q-switched Nd-YAG laser-ablation device works at the $5^{\text {th }}$ harmonic frequency corresponding to $213 \mathrm{~nm}$ wavelength. The ablation device is equipped with a programmable XYZ-stage to move the sample along the programmed trajectory during ablation. Target visual inspection and photographic documentation were achieved by built-in microscope/CCD-camera system.

A sample was enclosed in the SuperCell (New Wave Res., USA) and was ablated by the laser beam, which was focused onto the sample surface through a quartz window. The ablation cell was flushed with helium carrier gas which transported the laser-induced aerosol to the inductively coupled plasma (1 $1 / \mathrm{min})$. Sample argon gas flow was admixed with the helium carrier gas flow after laser ablation cell to $1.6 \mathrm{l} \mathrm{min}^{-1}$ total gas flow. NIST SRM 610 silicate glass reference material was used to optimise the gas flow rates, the sampling depth and MS electrostatic lens voltage in LA-ICP-MS conditions. This provided maximum signal to noise ratio and minimum oxide formation $\left(\mathrm{ThO}^{+} / \mathrm{Th}^{+}\right.$count ratio $0.2 \%, \mathrm{U}^{+} / \mathrm{Th}^{+}$counts ratio $1.1 \%$ ). Laser ablation required $100 \mu \mathrm{m}$ laser spot diameter, $8 \mathrm{~J} \mathrm{~cm}^{-2}$ laser fluence and $20 \mathrm{~Hz}$ repetition rate. The fixed sample position during laser ablation enabled $60 \mathrm{~s}$ hole-drilling duration for each spot. All element measurements were normalised on ${ }^{28} \mathrm{Si}$ in the investigated beryl.

\subsection{Powder X-ray diffraction analysis}

Powder X-ray diffraction analysis was carried out by BRUKER D8 Advance diffractometer (Laboratory of 


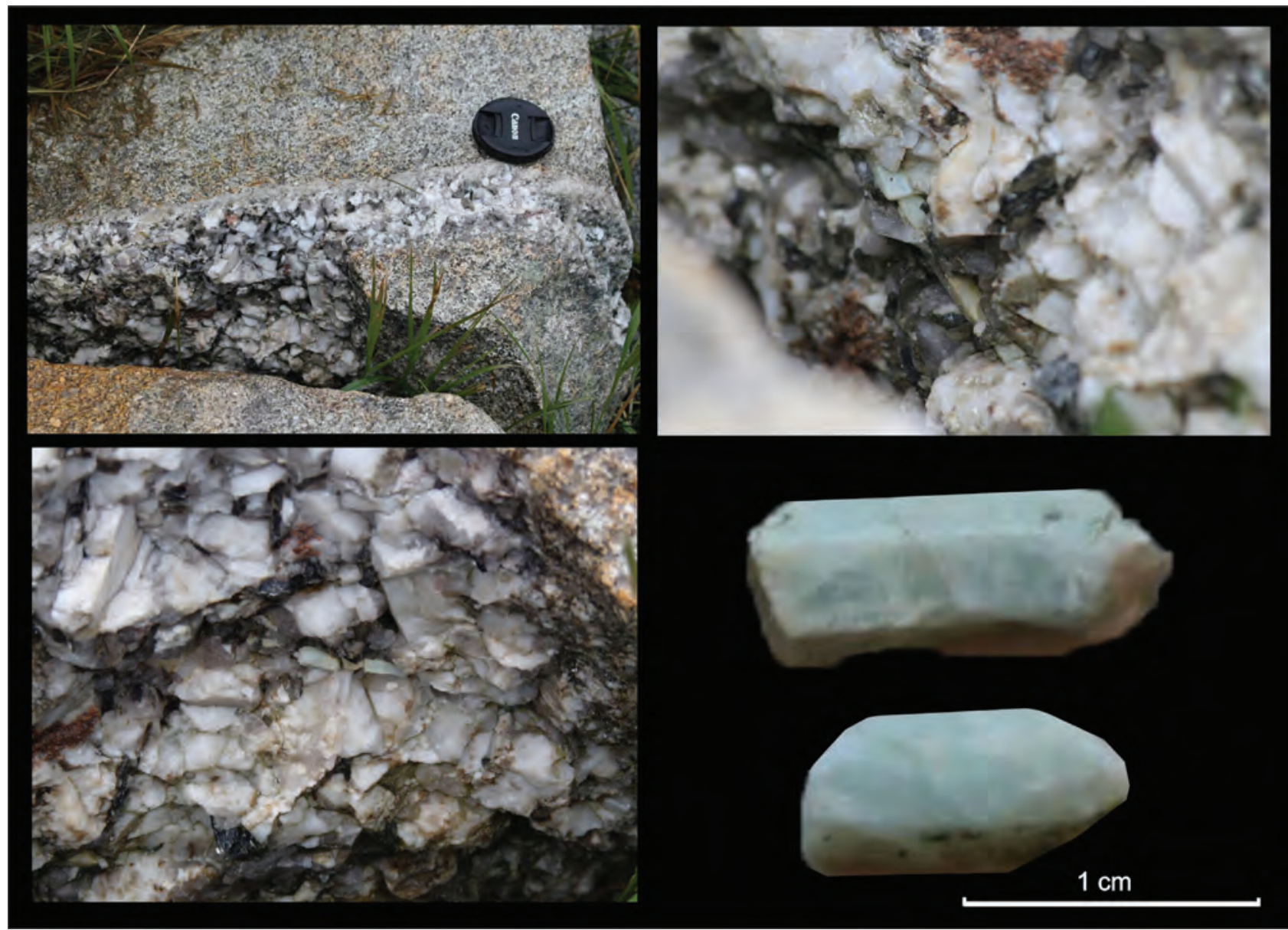

Fig. 2 Pegmatitic dike in granodiorite and details of blocky to core pegmatite zone.

X-ray diffraction SOLIPHA, Comenius University in Bratislava, Faculty of Natural Sciences) under the following conditions: Bragg-Brentano geometry (Theta2Theta), $\mathrm{Cu}$ anticathode $\left(K_{\alpha 1}=1.5406 \AA\right)$, accelerating voltage $40 \mathrm{kV}$ and beam current $40 \mathrm{~mA}$. Ni $K_{\beta}$ filters were used for stripping $K_{\beta}$ radiation, and data were obtained by BRUKER LynxEye detector. The step size was $0.01^{\circ} 2 \theta$, counting time $3 \mathrm{~s}$ per step and measurement ranged from 2 to $65^{\circ} 2 \theta$. Analysed scans were fitted and lattice parameters refined with DIFFRACplus TOPAS software using the beryl structural model (Aurisicchio et al. 1988).

\subsection{Fourier transform infrared (FTIR) and Raman spectroscopy}

Fourier transform infrared (FTIR) spectra in the 4000 $400 \mathrm{~cm}^{-1}$ IR region were obtained from powder by Nicolet 6700 spectrometer from Thermo Scientific (Institute of Inorganic Chemistry, Slovak Academy of Sciences, Bratislava) with a DTGS detector and $\mathrm{KBr}$ beam splitter. Spectra were collected by co-addition of 128 scans at a resolution of $4 \mathrm{~cm}^{-1}$. The $\mathrm{KBr}$ pressed-disc technique required $1 \mathrm{mg}$ of sample and $200 \mathrm{mg}$ of $\mathrm{KBr}$. The discs were heated in a furnace at $150^{\circ} \mathrm{C}$ overnight and spectra measured with a spectrometer purged with dry air to minimize water adsorption on both the sample and $\mathrm{KBr}$. The OMNICTM Thermo Electron Corporation software package was used for spectral handling and baseline subtraction.

The sample was sliced and the polished section used for Raman spectroscopy. Raman analysis was performed by LabRAM-HR Evolution (Horiba Jobin-Yvon) spectrometer system with a Peltier cooled CCD detector and Olympus BX-41 microscope (Earth Science Institute, Slovak Academy of Sciences, Banská Bystrica). Raman spectra were excited by $532 \mathrm{~nm}$ frequency-doubled Nd:YAG laser and a $520.6 \mathrm{~cm}^{-1}$ silicon wafer enabled spectral calibration. Spectra ranged from 100 to 4000 $\mathrm{cm}^{-1}$ with acquisition time of $10 \mathrm{~s}$ per frame and 2 accumulations.

Both infrared and Raman spectra were processed in Seasolve PeakFit 4.1.12 software. Raman and absorption bands were fitted by Lorentz function with automatic background correction and Savitzky-Golay smoothing. 
Octahedral substitution in beryl from Tatry Mts., Slovakia

\section{Results}

\subsection{Beryl description}

The studied beryl comes from a c. $10 \mathrm{~cm}$ thick dike of granitic pegmatite cutting biotite granodiorite. Beryl forms $\sim 1 \mathrm{~cm}$ long, pale blue-green euhedral to subhedral hexagonal prismatic crystals in blocky to core pegmatite zone (Fig. 2). Associated main minerals are quartz, K-feldspar, albite and muscovite, with accessory garnet (spessartine-almandine), zircon, apatite, and xenotime-(Y). Beryl contains anhedral to subhedral inclusions and intergrowths of quartz, K-feldspar, muscovite, epidote to clinozoisite and calcite (Fig. 3).

\subsection{Beryl chemical composition}

The studied beryl shows a weak chemical zoning due to variable octahedral- and channel-site occupancy. The relatively small core has growth zones with prismatic faces parallel to the $c$ axis enclosed by the pyramidal faces (Fig. 3a). The central core area has relatively low $\mathrm{Fe}$ and $\mathrm{Mg}$ contents but high $\mathrm{Na}$ (Tab. 1; Fig. 4, point 9). It is overgrown by the Fe- and Mg-rich zone with high $\mathrm{Na}$ content similar to central zone (Tab. 1; Fig. 4, points 6-9 and 10-11). The external part of the core is composed of beryl with low $\mathrm{Na}, \mathrm{Fe}$ and $\mathrm{Mg}$ content (Tab. 1; Fig. 4, points 3-5 and 12). The rim zone forms most of the crystal volume and has weak irregular chemical zoning with low $\mathrm{Na}$ and Mg dominating Fe (Tab. 1; Figs 3-4, points 1, 2 and 13).

The total Al content varies between 1.77 and 1.87 apfu; Al is substituted by Fe (0.03-0.07 apfu) and mostly by $\mathrm{Mg}(0.02-0.13 \mathrm{apfu})$. The decrease in octahedral site charge is balanced by alkali input in the channel: mostly Na (0.05-0.30 apfu). The resultant octahedral ${ }^{C} \mathrm{Na}^{O}(\mathrm{Fe}, \mathrm{Mg})^{C} \square_{-1}{ }^{O} \mathrm{Al}$, substitution results in a very good correlation (Fig. 5a). When the content of $\mathrm{Fe}_{\text {tot. }}$ and $\mathrm{Mg}$ as possible substituents at the octahedral site is compared to channel alkalis, the rim compositions with low octahedral substitution are above the ideal correlation line (Fig. 5b). This indicates possible presence of $\mathrm{Fe}^{3+}$. After the subtraction of excess Fe, the remainder can be treated as $\mathrm{Fe}^{2+}$. Consequently, it is possible to distinguish the influence of partial ${ }^{C} \mathrm{Na}^{O} \mathrm{Mg}^{C} \square_{-1}{ }^{O} \mathrm{Al}_{-1}$ and ${ }^{C} \mathrm{Na}^{O} \mathrm{Fe}^{C}$ $\square_{-1}{ }^{O} \mathrm{Al}_{-1}$ substitutions (Fig. $5 \mathrm{c}-\mathrm{d}$ ). Most compositions are Mg-dominant. When alkali content is compared to each cation, Na-poorer compositions display better correlation to $\mathrm{Mg}$ (Fig. 5c-d).

The dominance of octahedral substitution is also manifested in cell dimensions refined from powder XRD data (Tab. 2). The $c / a$ ratio is typical of "normal" beryl sensu Aurisicchio et al. (1988) but its relatively low value suggests octahedral substitution prevailing over tetrahedral one (Fig. 6). This is entirely consistent with EMPA data.

Laser-ablation analyses (Tab. 3) highlights the following; Cs has the highest concentrations of investigated beryl trace elements, with 2,800 to 4,000 ppm range and 
Tab. 2 Unit-cell parameters of the studied beryl and their assignment to a substitution series after Aurisicchio et al. (1988) compared to other Western Carpathian beryls

\begin{tabular}{|c|c|c|c|c|c|c|}
\hline & $a[\AA]$ & $c[\AA]$ & $V\left[\AA^{3}\right]$ & $c / a$ & & Reference \\
\hline Predné Solisko & $9.2199(5)$ & $9.1916(5)$ & $676.66(8)$ & 0.997 & normal & this work \\
\hline Bratislava - Švábsky Hill & $9.2248(3)$ & $9.2132(2)$ & $678.98(4)$ & 0.999 & tetrahedral & Uher et al. (2010) \\
\hline Bratislava - Líščia stráň & $9.2083(7)$ & $9.1847(8)$ & $674.46(12)$ & 0.997 & normal & Fridrichová et al. (2016) \\
\hline Bratislava - Dúbravka & $9.220(3)$ & $9.191(3)$ & $676.6(4)$ & 0.997 & normal & Fridrichová et al. (2016) \\
\hline Bratislava - Sitina & $9.2619(4)$ & $9.1837(7)$ & $682.26(7)$ & 0.992 & octahedral & Ozdín (2010) \\
\hline Moravany nad Váhom & $9.2179(3)$ & $9.2033(4)$ & $677.23(5)$ & 0.998 & normal & Uher et al. (2010) \\
\hline
\end{tabular}

3,200 ppm average. Other elements include $\mathrm{Ca}, \mathrm{K}, \mathrm{Li}, \mathrm{Zn}$, and Mn (100-670 ppm), Rb (15-50 ppm) and Ga (20-30 $\mathrm{ppm})$. The remaining measured trace elements in beryl reach only $<10 \mathrm{ppm}$. The $\mathrm{Cs} / \mathrm{Rb}$ ratio is 60-207 with 102 in average and $\mathrm{Cs} / \mathrm{Li}$ ratio is $5-32$ with 11 in average.

\subsection{Raman and FTIR spectroscopy}

The bands (Fig. 7; Tab. 4) observed in the powder IR spectrum of the studied sample were assigned to $A_{1 \mathrm{~g}}$ mode at 437, 522 and $747 \mathrm{~cm}^{-1}$, and bands associated

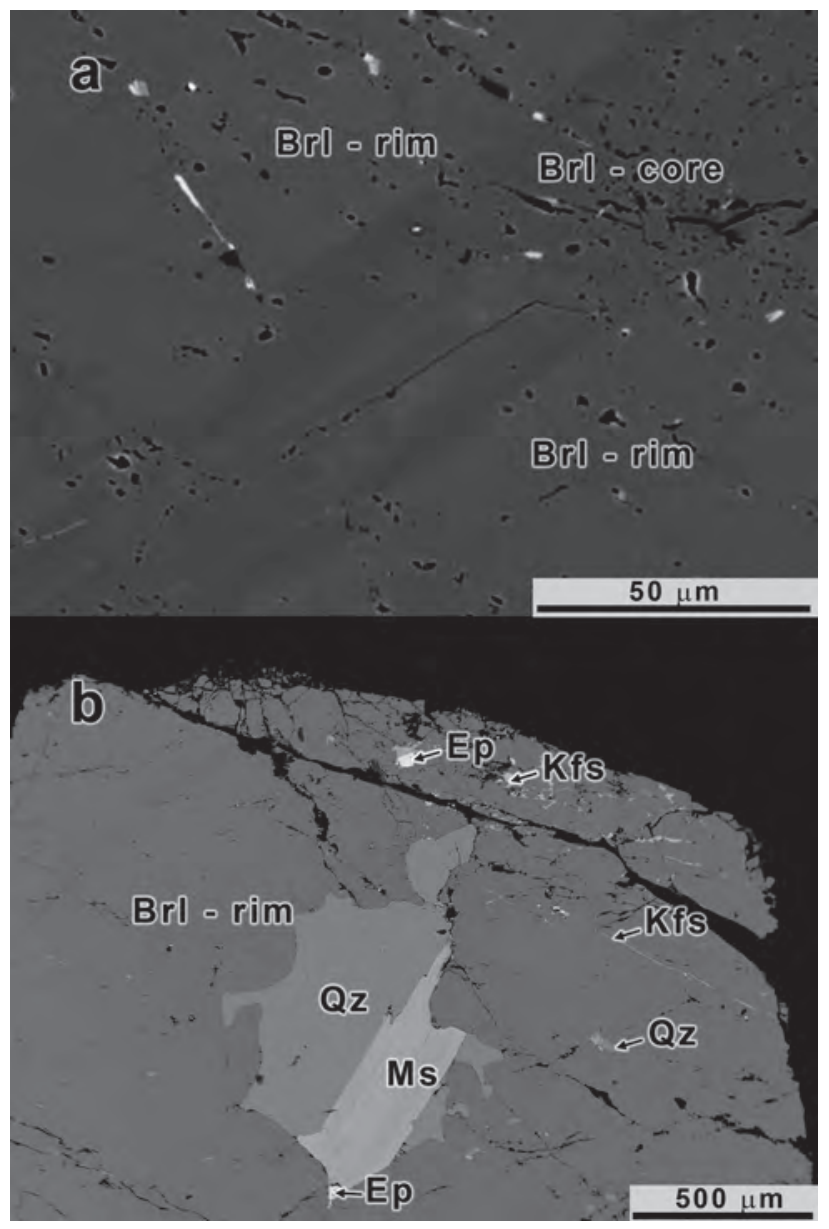

Fig. 3 Back-scattered electron (BSE) images of beryl (Brl): a - Detail of zoned core and relatively unzoned rim; $\mathbf{b}$ - Apical part of beryl crystal with inclusions of quartz (Qz), muscovite (Ms), K-feldspar (Kfs) and epidote (Ep). with $\mathrm{E}_{1 \mathrm{~g}}$ mode were 492, 592, 652, 681, 808, 957, 1020 and $1200 \mathrm{~cm}^{-1}$.

Water in the channel site was also studied by the powder IR spectroscopy (Fig. 7; Tab. 4); $\mathrm{H}_{2} \mathrm{O} \mathrm{I}-v_{2}, v_{3}$; $\mathrm{H}_{2} \mathrm{O}$ II $-v_{1 \mathrm{~s}, \mathrm{~d}}, v_{2 \mathrm{~s}}, v_{3}$ bands of two water types were detected. The first type is assigned to the following bands: (1) antisymmetric stretching mode $v_{3}$ for $3698 \mathrm{~cm}^{-1}$ and (2) bending vibration $v_{2}$ for $1603 \mathrm{~cm}^{-1}$. The second water type is connected with alkali cations. The range for $v_{1}$ is

Tab. 3 Minimal, maximal and average trace-element contents (in ppm) from 15 LA-ICP-MS spot analyses

\begin{tabular}{|c|c|c|c|c|}
\hline & Minimal & Maximal & Average & D.L. \\
\hline $\mathrm{Li}$ & 96 & 668 & 293 & 0.28 \\
\hline B & b.d.l. & 12.6 & 4.3 & 1.5 \\
\hline $\mathrm{K}$ & 147 & 3611 & 543 & 3.9 \\
\hline $\mathrm{Ca}$ & 216 & 600 & 400 & 45.3 \\
\hline Sc & 2.2 & 3.6 & 3.0 & 0.17 \\
\hline $\mathrm{Ti}$ & 2.0 & 7.4 & 4.7 & 0.51 \\
\hline V & 1.5 & 5.2 & 2.2 & 0.05 \\
\hline $\mathrm{Cr}$ & 0.0 & 1.5 & 0.2 & 0.27 \\
\hline $\mathrm{Mn}$ & 94 & 311 & 154 & 0.32 \\
\hline Co & 0.3 & 0.9 & 0.6 & 0.04 \\
\hline $\mathrm{Zn}$ & 148 & 268 & 204 & 0.23 \\
\hline $\mathrm{Ga}$ & 17 & 28 & 22 & 0.04 \\
\hline $\mathrm{Ge}$ & 1.2 & 3.9 & 2.0 & 0.22 \\
\hline $\mathrm{Rb}$ & 14 & 47 & 31 & 0.06 \\
\hline $\mathrm{Sr}$ & 0.4 & 7.2 & 3.7 & 0.03 \\
\hline Sn & 0.00 & 0.98 & 0.13 & 0.90 \\
\hline Cs & 2693 & 3919 & 3192 & 0.02 \\
\hline $\mathrm{Ba}$ & b.d.l. & 33 & 3 & 0.08 \\
\hline $\mathrm{Ce}$ & b.d.l. & 0.04 & 0.01 & 0.01 \\
\hline $\mathrm{Nd}$ & b.d.l. & 0.08 & 0.01 & 0.06 \\
\hline $\mathrm{Tb}$ & b.d.l. & 0.01 & b.d.l. & 0.01 \\
\hline Dy & b.d.l. & 0.05 & b.d.l. & 0.04 \\
\hline Er & b.d.l. & 0.06 & b.d.l. & 0.03 \\
\hline Tm & b.d.l. & 0.01 & b.d.l. & 0.01 \\
\hline $\mathrm{Yb}$ & b.d.l. & 0.08 & 0.02 & 0.00 \\
\hline $\mathrm{Lu}$ & b.d.l. & 0.01 & b.d.l. & 0.01 \\
\hline Hf & b.d.l. & 0.05 & 0.01 & 0.00 \\
\hline $\mathrm{Ta}$ & b.d.l. & 0.25 & 0.06 & 0.01 \\
\hline $\mathrm{Tl}$ & b.d.l. & 1.97 & 0.95 & 0.46 \\
\hline $\mathrm{Pb}$ & 0.09 & 0.96 & 0.52 & 0.02 \\
\hline Th & b.d.l. & 6.46 & 0.43 & 0.00 \\
\hline $\mathrm{U}$ & b.d.l. & 0.97 & 0.17 & 0.01 \\
\hline
\end{tabular}

D.L. - detection limit, b.d.1. - below the detection limit 

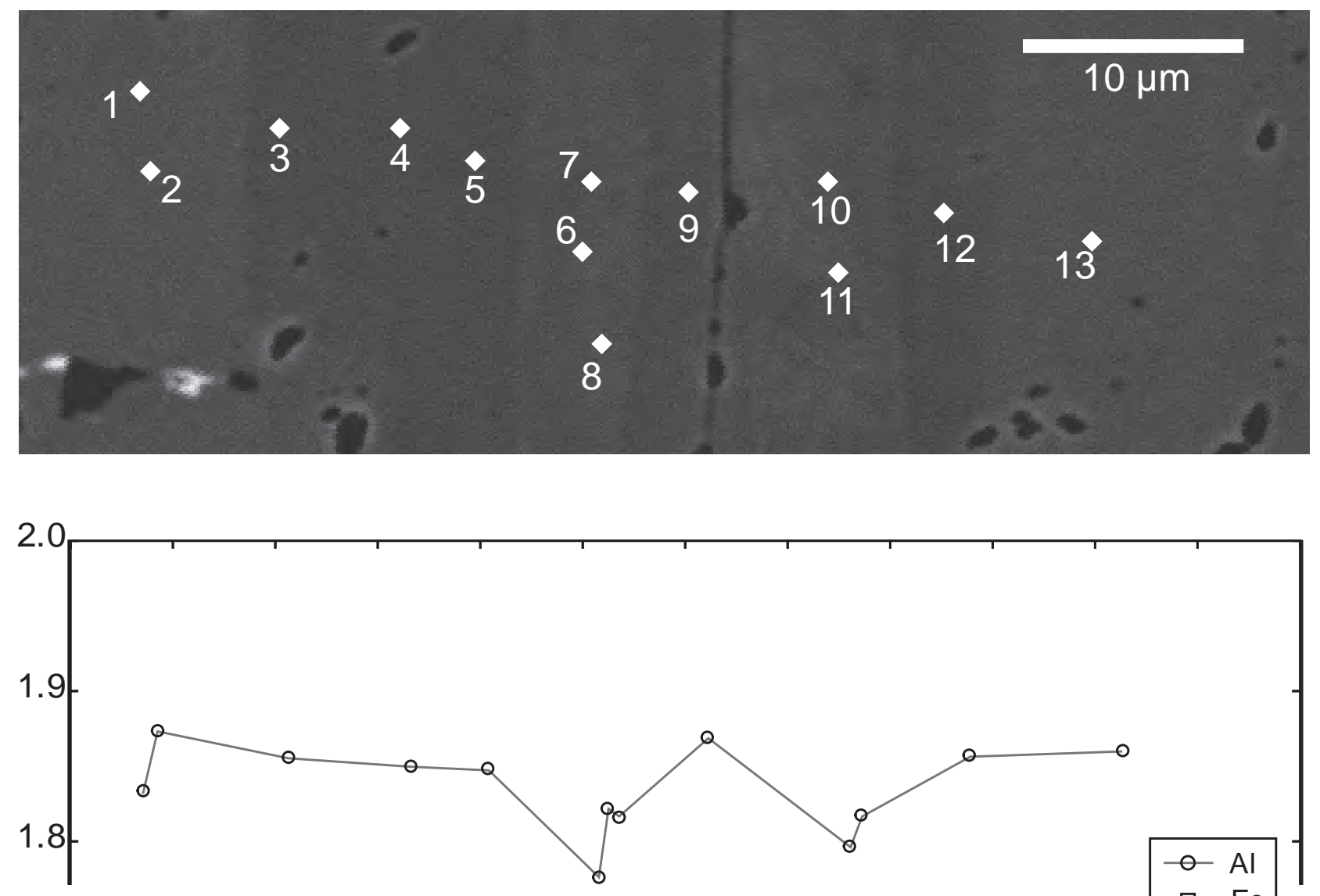

$\odot \mathrm{Al}$
$\square-\mathrm{Fe}$
$\diamond \mathrm{Mg}$
$\triangle \mathrm{Na}$

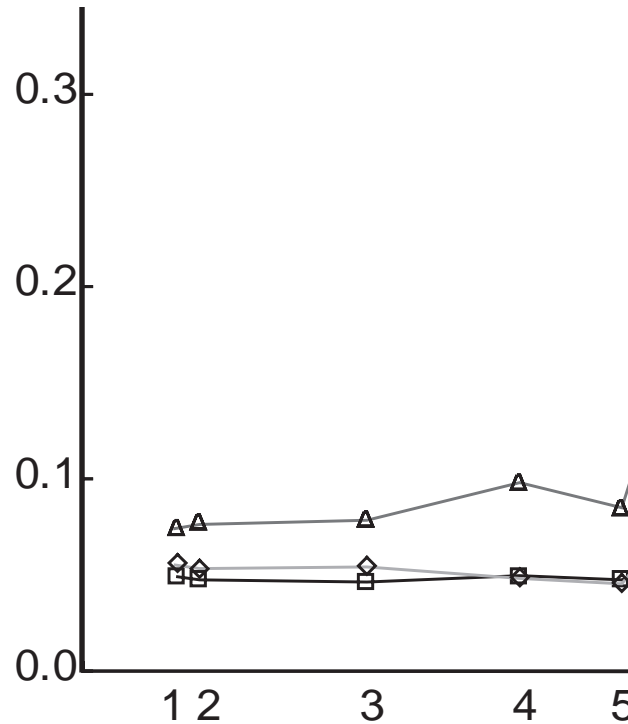

Fig. 4 Compositional profile (lower image, plotted in apfu) across beryl core (upper BSE image).

3588-3598 $\mathrm{cm}^{-1}$ - singly and doubly coordinating $\mathrm{H}_{2} \mathrm{O}$, for $v_{3} 3656 \mathrm{~cm}^{-1}$, and for $v_{2} 1635 \mathrm{~cm}^{-1}$. All these bands agree with published values (Łodziński et al. 2005; Fukuda and Shinoda 2008).

The Raman bands (Fig. 8; Tab. 5) were assigned to $A_{1 \mathrm{~g}}$ modes at 322, 397, 686, and $1068 \mathrm{~cm}^{-1}, \mathrm{E}_{1 \mathrm{~g}}$ at 141, 526, 762 and $1011 \mathrm{~cm}^{-1}$ and $\mathrm{E}_{2 \mathrm{~g}}$ modes at 420,
445, 563, $776 \mathrm{~cm}^{-1}$. Raman spectroscopy was also performed for water behaviour (Fig. 8; Tab. 5). We distinguished only $v_{1}$ assigned to $3608 \mathrm{~cm}^{-1}$ for water type I and $3597 \mathrm{~cm}^{-1}$ for water type II. No other water vibrations were determined by Raman spectroscopy. This is most likely due to random sample orientation to the laser beam. 

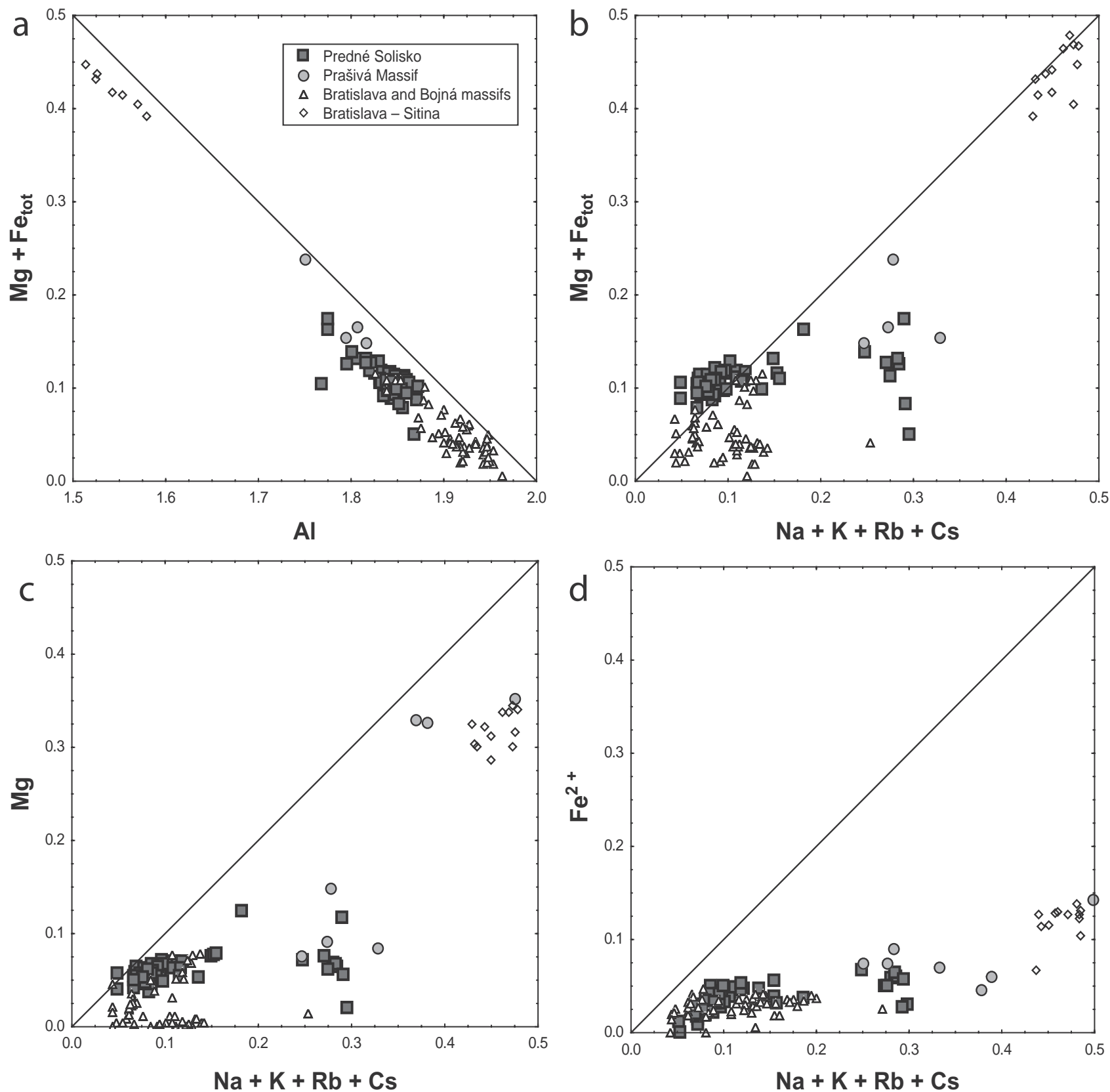

Fig. 5 Octahedral substitution diagram (a) and diagrams comparing $\mathrm{Mg}+\mathrm{Fe}_{\text {tot. }}$ sum (b), $\mathrm{Mg}$ (c) and $\mathrm{Fe}^{2+}$ (d) to $\mathrm{Na}+\mathrm{K}+\mathrm{Rb}+\mathrm{Cs}$ contents. The pegmatites with an affinity to $I$-type source granitoids (Predné Solisko and Prašivá) are indicated by grey symbols. Prašivá Massif beryl analyses are taken from Fridrichová et al. (2016), Bratislava and Bojná massifs from Uher et al. (2010), Fridrichová et al. (2016) and Bratislava - Sitina beryl from Ozdín (2010).

\section{Discussion and conclusions}

Octahedral substitutions are homovalent for trivalent cations $\mathrm{Fe}^{3+}, \mathrm{Mn}^{3+}, \mathrm{Cr}^{3+}, \mathrm{V}^{3+}$, and $\mathrm{Sc}^{3+}$ and heterovalent for cations with different charges. These latter require charge-balance by including alkalis such as $\mathrm{Na}^{+}, \mathrm{K}^{+}, \mathrm{Rb}^{+}$ or $\mathrm{Cs}^{+}$in the channel sites (Aurisicchio et al. 1994).

Predné Solisko beryl, and other beryls from the Western Carpathians, are exceptional in their conformity. They are very close to end-member composition and contain no significant amounts of minor or trace elements except $\mathrm{Fe}, \mathrm{Mg}, \mathrm{Na}$ and $\mathrm{Cs}$ (Uher et al. 2010; Ozdín 2010; Fridrichová et al. 2016). As previously noted, Fe and $\mathrm{Mg}$ affinity to octahedral substitution is expected and documented (Fig. 5a).

Aluminum is the main element at the octahedral site, $\mathrm{Mg}$ and $\mathrm{Fe}$ are its other major substituents. Magnesium is a typical octahedral constituent, although similar ionic radius (0.57 ̊; Shannon 1976) to Li makes it appropriate for tetrahedral coordination. Interestingly, Meagher 
Tab. 4 Infrared bands and their assignment

\begin{tabular}{|c|c|c|c|}
\hline & & References & Sample \\
\hline \multirow[t]{3}{*}{$A_{1 g}$} & & 1 & 437 \\
\hline & & 1 & 522 \\
\hline & & 1 & 747 \\
\hline \multirow[t]{14}{*}{$E_{1 \mathrm{~g}}$} & & 1 & 492 \\
\hline & & 1 & 592 \\
\hline & & 1 & 652 \\
\hline & & 1 & 681 \\
\hline & & 1 & 808 \\
\hline & $\mathrm{Si}-\mathrm{O}$ & 1 & 957 \\
\hline & $\mathrm{Si}-\mathrm{O}$ & 1 & 1020 \\
\hline & $\mathrm{Si}-\mathrm{O}$ & 1 & 1200 \\
\hline & $\mathrm{H}_{2} \mathrm{O} \mathrm{I} v_{2}$ & 2,3 & 1603 \\
\hline & $\mathrm{H}_{2} \mathrm{O}$ II $v_{2}$ & 2,3 & 1635 \\
\hline & $\mathrm{H}_{2} \mathrm{O}$ IIs $v_{1}$ & 2,3 & 3588 \\
\hline & $\mathrm{H}_{2} \mathrm{O}$ IId $v_{1}$ & 2,3 & 3598 \\
\hline & $\mathrm{H}_{2} \mathrm{O} \mathrm{II} v_{3}$ & 2,3 & 3656 \\
\hline & $\mathrm{H}_{2} \mathrm{O} \mathrm{I} \mathrm{v}$ & 2,3 & 3698 \\
\hline
\end{tabular}

References: 1 - Adams and Gardner (1974); 2 - Lodziński et al. (2005); 3 - Fukuda and Shinoda (2008)

and Gibbs (1968) reported that $\mathrm{Mg}$ in high-temperature treated cordierite engendered disorder with $\mathrm{Al}$ at octahedral and tetrahedral sites. However, the specific disorder environment and the slight difference in cordierite and beryl structures suggest that the $\mathrm{Mg}$ presence at the tetrahedral site of the untreated beryl is unlikely. Therefore, we can presume that all $\mathrm{Mg}$ is at the octahedral site and contributes to the octahedral substitution.

Iron could be present in both ferrous and ferric states, but its content is too low for Mössbauer spectroscopic analysis. Ferric iron is usually located in octahedra (Aurisicchio et al. 1988) but some authors suggested its presence in Be tetrahedron (Andersson 2013) or channel sites (Blak et al. 1982). In contrast, $\mathrm{Fe}^{2+}$ is usually located

Tab. 5 Raman bands and their assignment

\begin{tabular}{llcc}
\hline & & References & Sample \\
\hline $\mathrm{A}_{1 \mathrm{~g}}$ & ring & $1,2,3$ & 322 \\
& ring & $1,2,3$ & 397 \\
& $\mathrm{Be}-\mathrm{O}$ & $1,2,3$ & 686 \\
& $\mathrm{Si}-\mathrm{O}$ & $1,2,3$ & 1068 \\
$\mathrm{E}_{1 \mathrm{~g}}$ & & 1,3 & 141 \\
& $\mathrm{Al}-\mathrm{O}$ & $1,2,3$ & 526 \\
& & 1,3 & 762 \\
& & $1,2,3$ & 1011 \\
$\mathrm{E}_{2 \mathrm{~g}}$ & $\mathrm{Si}-\mathrm{O}$ & 1,3 & 420 \\
& & 1,3 & 445 \\
& & 1,3 & 563 \\
& & 4,3 & 776 \\
\cline { 3 - 4 } & & 4,5 & 3597 \\
& $\mathrm{H}_{2} \mathrm{O} \mathrm{II} v_{1}$ & 4608 \\
\hline
\end{tabular}

References: 1 - Adams and Gardner (1974); 2 - Charoy et al. (1996); 3 - Hagemann et al. (1990); 4 - Lodziński et al. (2005); 5 - Fukuda and Shinoda (2008)
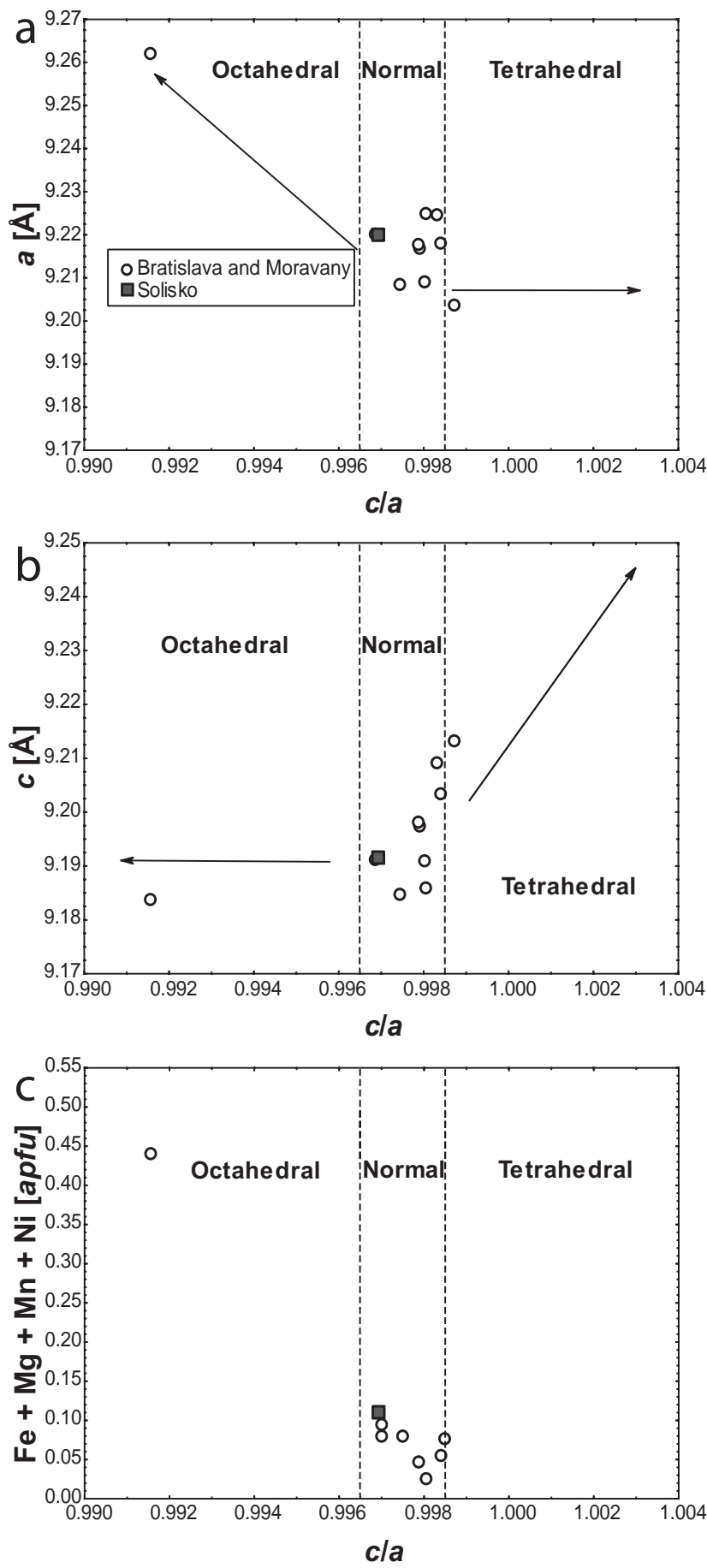

Fig. 6 Diagrams comparing (a) $a$, (b) $c$ size and (c) divalent octahedral cations content to c/a ratio with a division to beryl types according to Aurisicchio et al. (1988).

not only in octahedra (Aurisicchio et al. 1988) but also at channel sites (e.g., Wood and Nassau 1968; Goldman et al. 1978; Viana et al. 2002). These interpretations locating $\mathrm{Fe}$ in sites other than octahedra are based only on the spectroscopic data without thorough structural proof.

The possible occurrence of $\mathrm{Fe}^{3+}$ or $\mathrm{Fe}^{2+}$ as (almost) free ions at both channel sites are based on electron 


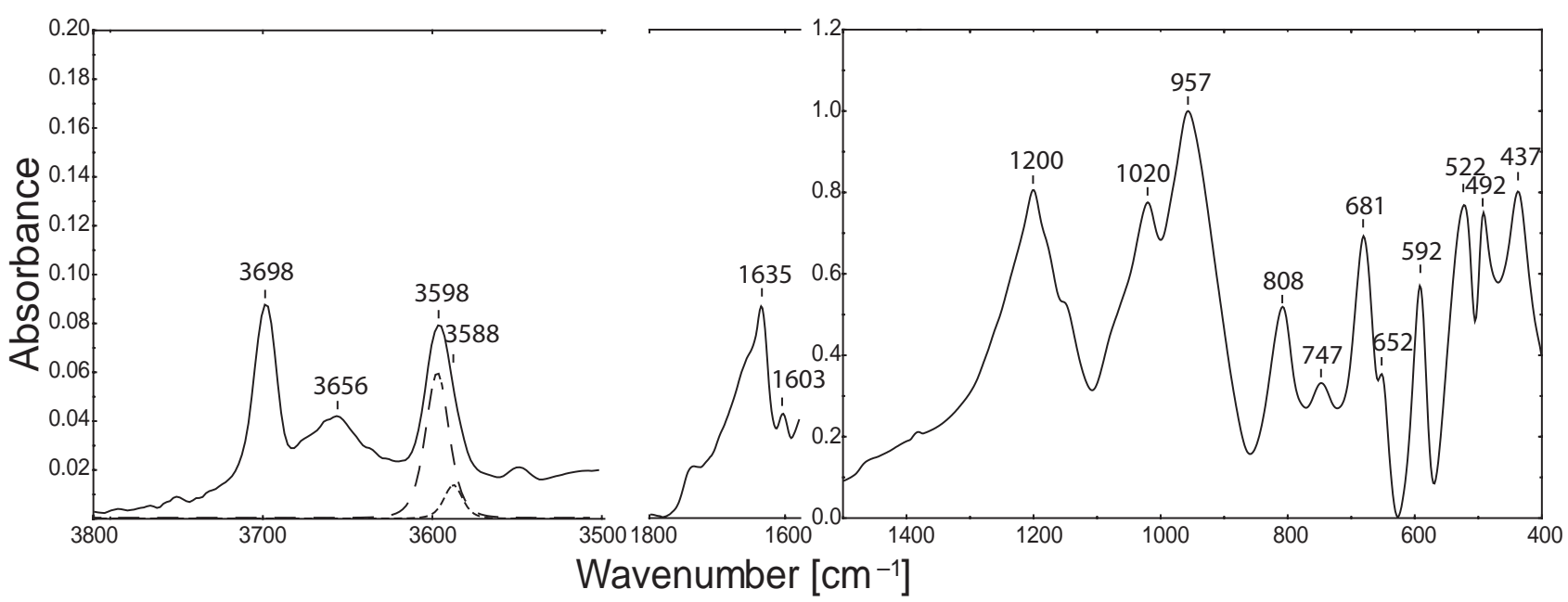

Fig. 7 Infrared spectrum of beryl from Predné Solisko.

paramagnetic resonance (EPR) spectroscopy (Blak et al. 1982, 1983). However, later interpretation suggested that the observed spectral geometry attributed to $\mathrm{Fe}^{3+}$ at hexagonal symmetrical sites can also be due to the presence of electrons and holes trapped at crystallographically equivalent sites around a threefold axis (Lehmann 1983; Andersson 2013). Moreover, isolated ions with negligible electrostatic interactions with ring oxygens also do not contribute to substitutions in the beryl structural framework.

Magnesium has a weak positive correlation to $\mathrm{Na}$ in Na-poor compositions which implies that $\mathrm{Mg}$ is the dominant substituent in the octahedron (Fig. 5c). This general trend in Predné Solisko is similar to other beryl samples from Western Carpathians used for the comparison. Moreover, the $\mathrm{Fe}+\mathrm{Mg}$ excess in low-alkali compositions in studied beryl indicates the $\mathrm{Fe}^{3+}$ presence. Unfortunately, this cannot be proven by Mössbauer spectroscopy due to the too low total Fe content in the studied sample.
The dominant substitutions directly influence the unitcell parameters. Divalent cations increase the octahedral $\mathrm{R}-\mathrm{O}$ bond lengths. This is then constrained by the short edges shared with Be tetrahedra and is flattened in the $c$ direction. Increased bond length directly influences $a$ size, thus enabling beryl to be divided into three series: (1) "octahedral" beryl with 0.991-0.996 c/a ratio; (2) "tetrahedral" beryl with 0.999-1.003 c/a ratio and (3) "normal" beryl with $0.997-0.998 c / a$ ratio. There is a compositional gap between tetrahedral and octahedral beryl (Aurisicchio et al. 1988). The beryl studied herein belongs to the "normal" group but its relatively lower $c / a$ ratio indicates an affinity to the "octahedral" type (Fig. 6).

Aurisicchio et al. (1994) recorded further discrimination for beryl substitutions based on spectroscopic data. The decrease in wavenumber of $\mathrm{Si}-\mathrm{O}$ vibration $\sim 1200 \mathrm{~cm}^{-1}$ band in the FTIR spectra depends on the extent of both tetrahedral and octahedral substitution (Fig 9a-b). Beryl from Predné Solisko with exactly $1200 \mathrm{~cm}^{-1}$ band fall on the lower extremity of normal

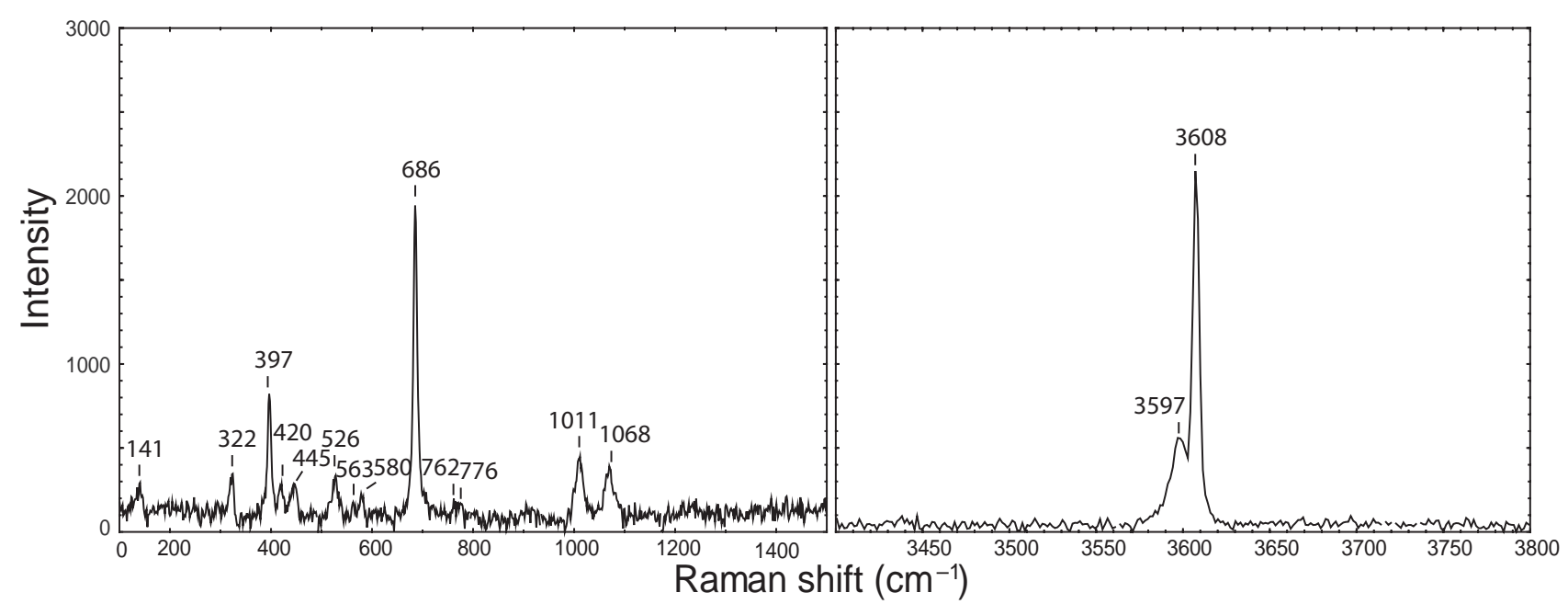

Fig. 8 Raman spectrum of beryl from Predné Solisko. 

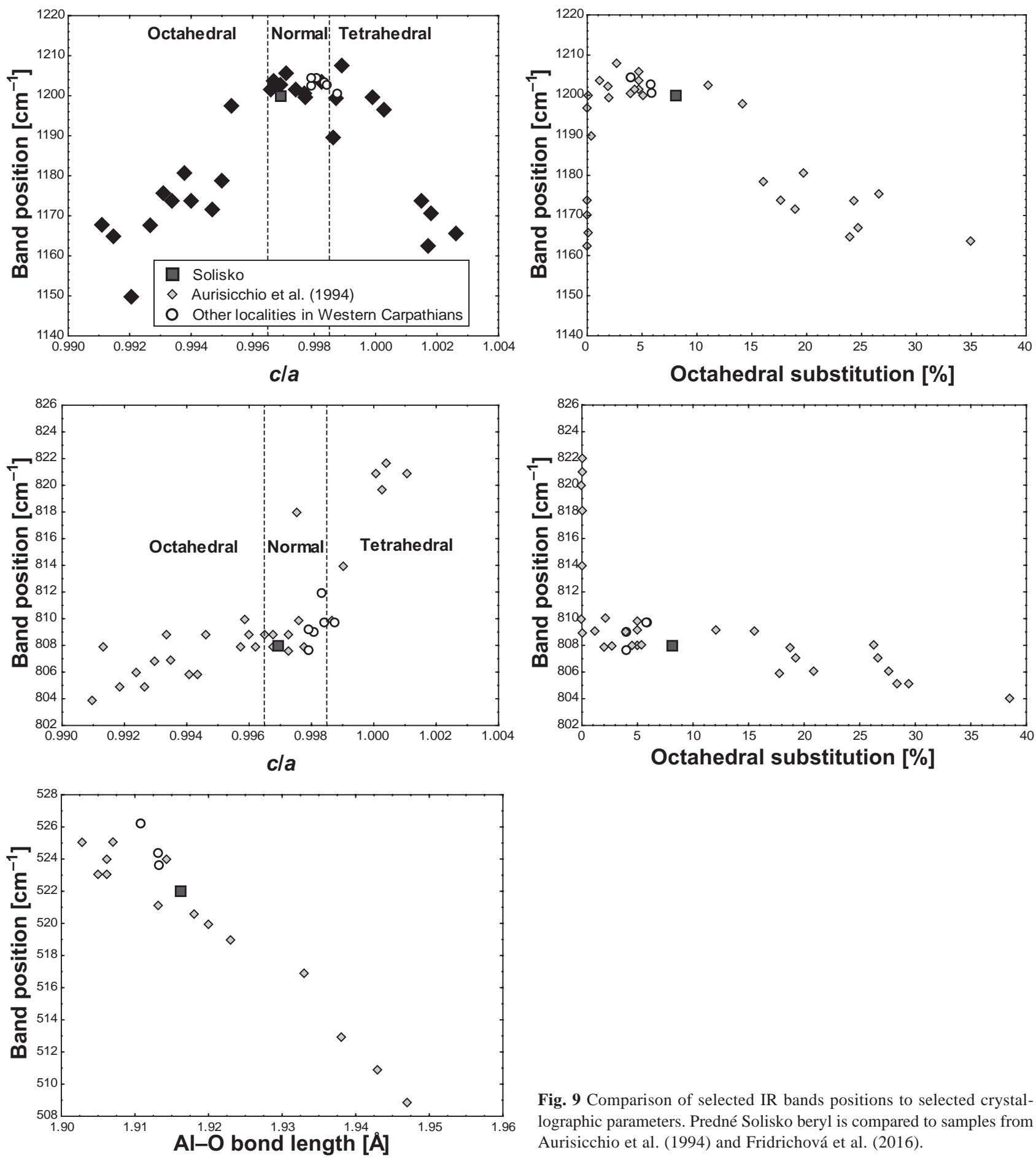

beryl with significant affinity to octahedral group. The position of the $\sim 810 \mathrm{~cm}^{-1} \mathrm{Be}-\mathrm{O}$ vibration band is sensitive to tetrahedral substitution with a large increase in wavenumber to $820 \mathrm{~cm}^{-1}$ in beryl with the most extensive tetrahedral substitution (Fig. 9c-d). Normal and octahedral beryl, including the studied one, vary between 803 and $810 \mathrm{~cm}^{-1}$. The most obvious correlation in octahedral beryl is between $520 \mathrm{~cm}^{-1}$ band positions and the $\mathrm{Al}-\mathrm{O}$ bond length (Fig. 9e). In the absence of

Fig. 9 Comparison of selected IR bands positions to selected crystallographic parameters. Predné Solisko beryl is compared to samples from Aurisicchio et al. (1994) and Fridrichová et al. (2016).

structural data, $\mathrm{Al}-\mathrm{O}$ bond length was calculated by the empirical formula $(\mathrm{Al}-\mathrm{O})=-0.0654 \times \mathrm{Al} p f u+2.0364$ after Aurisicchio et al. (1988). Beryl values from Predné Solisko and those from Western Carpathians (Uher et al. 2010; Fridrichová et al. 2016) follow the general trend. Spectroscopic data provide an indirect source of information on beryl composition and shows that the studied Predné Solisko beryl has affinity to octahedral substitution. 
There were several attempts made to reveal the relationship between the degree of octahedral substitution in beryl and genetic conditions. Elevated content of Fe and $\mathrm{Mg}$ in beryl is typical of less fractionated or contaminated Li-poor granitic pegmatites (e.g., Schaller et al. 1962; Aurisicchio et al. 1988, 2012; Uher and Broska 1995; Černý 2002, Černý et al. 2003, Wang et al. 2009; Novák and Filip 2010; Uher et al. 2010; Aurisicchio et al. 2012; Prrikryl et al. 2014). Primitive characteristics of the examined beryl samples may reflect a low degree of fractionation of the host pegmatite (Prrikryl et al. 2014), a high degree of external Mg-contamination from host metabasites in thin pegmatite dikes (Novák et al. 2013), or a combination of both.

Until now, no clear relationship between $\mathrm{Mg} / \mathrm{Fe}$ and $\mathrm{Fe}^{2+} / \mathrm{Fe}^{3+}$ ratios in beryl and affinity of the individual pegmatite bodies to the NYF or LCT family was found (Černý et al. 2012). Moreover, $\mathrm{Fe}^{2+}$ typically dominates over $\mathrm{Fe}^{3+}$ in beryl from all granitic pegmatites examined (Aurisicchio et al. 1988; Přikryl et al. 2014). However, the intragranitic position of the Predné Solisko pegmatite excludes the external contamination and thus its relation to the source biotite granodiorite is obvious.

Slovak pegmatite bodies are usually intragranitic and dominantly derived from $S$-type peraluminous granitic plutons, but exceptions are the Prašivá and Vysoké Tatry pegmatites related to $I$ - or mixed I/S-type granitic rocks (Petrík et al. 1994; Uher and Broska 1995; Broska and Uher 2001). Slovak pegmatites are also relatively weakly fractionated, and this includes those from Predné Solisko.

Moreover, there is a distinct link between beryl composition and the source of pegmatitic melt. The granitic rocks with $I$ - to $I / S$-type affinity are generally richer in $\mathrm{Mg}$ than the $S$-type granites in the Western Carpathians (Broska and Uher 2001). Consequently, the ${ }^{C} \mathrm{Na}^{O} \mathrm{Mg}^{\mathrm{C}}$ $\square_{-1}{ }^{O} \mathrm{Al} l_{-1}$ substitution plays a more important role in beryl from I- or $I / S$-type derived pegmatites such as Predné Solisko. This relationship is evident also for Fe,Mg-poor beryl from $S$-type related pegmatites (Bratislava and Bojná massifs) if compared with Fe,Mg-bearing beryl from I- (I/S)-type related granites in the Prašivá Massif of the Western Carpathians (Uher and Broska 1995), beryls in intragranitic pegmatites derived from Mg-poor granites are usually also Mg-poor (Lum et al. 2016).

Beryl zoning also indicates crystallisation sequence and the host pegmatite magmatic evolution. The Predné Solisko beryl core is relatively Na-rich, whereas the rim has distinctly lower $\mathrm{Na}$ content. This implies that the crystallization of albite as an essential Na carrier followed beryl core formation. Consequently, albite precipitation may have resulted in the strongly decreased $\mathrm{Na}$ concentration in the melt so that this element was no longer available for the later stages of beryl crystallisa- tion. Hence, the degree of the octahedral substitution in beryl is also limited.

Acknowledgements. We thank Milan Novák for editorial handling and D. Marschall and an anonymous reviewer for their detailed reviews that improved the quality of our work. We also thank Viera Kollárová for her assistance during the electron-microprobe work and Ray Marshall for improving language of the manuscript. This work was supported by the Slovak Research and Development Agency projects No. APVV-14-0278, APVV-15-0050 and APVV-17-0134, as well as the Ministry of Education of Slovak Republic Grant Agency under the contracts VEGA-1/0079/15 and VEGA-1/0499/16.

\section{References}

ADAMS DM, GARDNER IR (1974) Single-crystal vibrational spectra of beryl and dioptase. J Chem Soc Dalton Trans 14: $1502-1505$

ANDERSSON LO (2013) The yellow color center and trapped electrons in beryl. Canad Mineral 51: 15-25

Andrusov D (1968) Grundriss der Tektonik der Nördlichen Karpaten. VEDA, Bratislava, pp 1-188

Aurisicchio C, Fioravanti G, Grubessi O, Zanazzi PF (1988) Reappraisal of the crystal chemistry of beryl. Amer Miner 73: 826-837

Aurisicchio C, Grubessi O, Zecchini P (1994) Infrared spectroscopy and crystal chemistry of the beryl group. Canad Mineral 32: 55-68

Aurisicchio C, Conte AM, De Vito C, Ottolini L (2012) Beryl from miarolitic pockets of granitic pegmatites, Elba, Italy: characterization of crystal chemistry by means of EMP and SIMS analyses. Canad Mineral 50: 1467-1488

Beal K-L, Lentz DR (2010) Aquamarine beryl from Zealand Station, Canada: a mineralogical and stable isotope study. J Geosci 55: 57-67

BLAK AR, ISOTANI S, WATANABE S (1982) Optical absorption and electron spin resonance in blue and green natural beryl. Phys Chem Miner 8: 161-166

BLAK AR, IsOTANi S, WataNABE S (1983) Optical absorption and electron spin resonance in blue and green natural beryl: a reply. Phys Chem Miner 9: 279-280

BRosKA I, UHER P (2001) Whole-rock chemistry and genetic typology of the West-Carpathian Variscan granites. Geol Carpath 52: 79-90

Charoy B, De Donato P, Barres O, Pinto-Coelho C (1996) Channel occupancy in an alkali-poor beryl from Serra Branca (Goias, Brazil): spectroscopic characterization. Amer Miner 81: 395-403

ČERNÝ P (2002) Mineralogy of beryllium in granitic pegmatites. In: Grew ES (ed) Beryllium: Mineralogy, Petrology 
and Geochemistry. Mineralogical Society of America Reviews in Mineralogy and Geochemistry 50: 405-444

ČERNÝ P, ERCIT TS (2005) The classification of granitic pegmatites revisited. Canad Mineral 43: 2005-2026

ČERnÝ P, ANDERSONAJ, TOMASCAK PB, ChaPMAN R (2003) Geochemical and morphological features of beryl from the Bikita granitic pegmatite, Zimbabwe. Canad Mineral 41: 1003-1011

ČERnÝ P, London D, NovÁK M (2012) Granitic pegmatites as reflections of their sources. Elements 8: 289-294

Fiala F (1931) Some mineralogical findings from Žiar Mountains. Sbor Prírod Odb Slov Vlastived Muz Bratislava 1924-1931: 24-27 (in Czech)

Fridrichová J, Bačík P, Bizovská V, Libowitzky E, ŠKodA R, UHER P, Ozdín D, ŠTEVKo M (2016) Spectroscopic and bond-topological investigation of interstitial volatiles in beryl from Slovakia. Phys Chem Miner 43: 419-437

FuKUdA J, SHINODa K (2008) Coordination of water molecules with $\mathrm{Na}^{+}$cations in a beryl channel as determined by polarized IR spectroscopy. Phys Chem Miner 35: 347-357

GARGULÁK M, VANEK J (1989) Beryl - a first finding from the Malé Karpaty pegmatites. Mineralia Slov 21: 426 (in Slovak)

Gawęda A, Burda J, Klötzli U, Golonka J, Szopa K (2016) Episodic construction of the Tatra granitoid intrusion (Central Western Carpathians, Poland/Slovakia): consequences for the geodynamics of Variscan collision and Rheic Ocean closure. Int J Earth Sci 105: 1153-1174

Giuliani G, France-Lanord C, Zimmermann JL, Cheilletz A, Arboleda C, Charoy B, Coget P, Fontan F, Giard D (1997) Fluid composition, $\delta \mathrm{D}$ of $\mathrm{H}_{2} \mathrm{O}$ and $\delta^{18} \mathrm{O}$ of lattice oxygen in beryls: genetic implications for Brazilian, Colombian and Afghanistani emerald deposits. Int Geol Rev 39: 400-424

Goldman DS, Rossman GR, Parkin KM (1978) Channel constituents in beryl. Phys Chem Miner 3: 225-235.

Groat LA, Rossman GR, Dyar MD, Turner D, Piccoli PMB, Schultz AJ, Ottolini L (2010) Crystal chemistry of dark blue aquamarine from the True Blue showing, Yukon Territory, Canada. Canad Mineral 48: 597-613

Hagemann A, Lucken A, Bill H, Gysler-Sanz J, Stalder HA (1990) Polarized Raman spectra of beryl and bazzite. Phys Chem Miner 17: 395-401

Hók J, ŠUjan M, ŠIPKa F (2014) Tectonic division of the Western Carpathians: an overview and a new approach. AGEOS 6: 135-143

JANÁK M (1994) Variscan uplift of the crystalline basement, Tatra Mts, Central Western Carpathians: evidence from ${ }^{40} \mathrm{Ar} /{ }^{39} \mathrm{Ar}$ laser probe dating of biotite and $\mathrm{P}-\mathrm{T}-\mathrm{t}$ paths. Geol Carpath 45: 293-300

KoHÚT M, SHERLOCK S (2003) Laser microprobe ${ }^{40} \mathrm{Ar}-{ }^{39} \mathrm{Ar}$ analysis of pseudotachylite and host rocks from the Tatra
Mountains, Slovakia: evidence for Late Paleogene seismic/tectonic activity. Terra Nova 15: 417-424

Králiková S, Vojtko R, SLiva L', Minár J, FüGenschun B, Kováč M, Hók J (2014) Cretaceous-Quaternary tectonic evolution of the Tatra Mts. (Western Carpathians): constraints from structural, sedimentary, geomorphological, and fission track data. Geol Carpath 65: 307-326

Lehmann G (1983) Optical absorption and electron spin resonance in blue and green natural beryl: a comment. Phys Chem Miner 9: 278

Łodziński M, Sitarz M, Stec K, Kozanecki M, FoJud Z, JURGA S (2005) ICP, IR, Raman, NMR investigations of beryls from pegmatites of the Sudety Mts. J Molecul Struct 2005: 1005-1015

London D (2008) Pegmatites. The Canadian Mineralogist, Special Publications 10. Mineralogical Association of Canada, Québec, pp 1-347

London D, Evensen JM (2002) Beryllium in silicic magmas and the origin of beryl-bearing pegmatites. In: Grew ES (ed) Beryllium: Mineralogy, Petrology, and Geochemistry. Mineralogical Society of America Reviews in Mineralogy and Geochemistry 50: 445-486

Lum J, Viljoen F, Cairncross B, Frei D (2016) Mineralogical and geochemical characteristics of beryl (aquamarine) from the Erongo Volcanic Complex, Namibia. J Afr Earth Sci 124: 104-125

Mahes M (1986) Geology of the Czechoslovak Carpathians, Paleoalpine Units. VEDA, Bratislava, pp 1-505 (in Slovak)

Meagher EP, GibBs GV (1968) Tetrahedral magnesium in cordierite. Geological Society of America Special Papers 115: 146

NovÁK M, FILIP J (2010) Unusual (Na, Mg)-enriched beryl and its breakdown products (beryl II, bazzite, bavenite) from euxenite-type NYF pegmatite related to the orogenic ultrapotassic Třebíč Pluton, Czech Republic. Canad Mineral 48: 615-628

Novák M, Kadlec T, Gadas P (2013) Geological position, mineral assemblages and contamination of granitic pegmatites in the Moldanubian Zone, Czech Republic; examples from the Vlastějovice region. J Geosci 58: 21-47

OzDín D (2010) Beryl and phenakite from granitic pegmatites of the Sitina tunnel in Bratislava (Slovak Republic). Bull mineral-petrol Odd Nár Muz (Praha) 18: 78-84 (in Slovak)

PešKová I, Vojtko R, Starek D, Sliva K (2009) Late Eocene to Quaternary deformation and stress field evolution of the Orava region (Western Carpathians). Acta Geol Pol 59: 73-91

Petrík I, Broska I, Uher P (1994) Evolution of the Western Carpathian granite magmatism: age, source rock, geotectonic setting and relation to the Variscan structure. Geol Carpath 45: 283-291 
PITOŇÁK P, JANÁK M (1983) Beryl - new mineral from pegmatites in Nízke Tatry Mts. Mineralia Slov 15: 231-232 (in Slovak)

Plašienka D (1999) Tectonochronology and Paleotectonic Model of the Jurassic-Cretaceous Evolution of the Central Western Carpathians. Veda, SAV, Bratislava, pp 1-127 (in Slovak)

Poller U, TODT W (2000) U-Pb single zircon data of granitoids from the High Tatra Mountains (Slovakia): implications for the geodynamic evolution. Trans Roy Soc Edinb, Earth Sci 91: 235-243

Poller U, JanÁK M, Kohút M, TodT W (2000) Early Variscan magmatism in the Western Carpathians: U-Pb zircon data from granitoids and orthogneisses of the Tatra Mountains (Slovakia). Int J Earth Sci 89: 336-349

P̌̌ikryl J, Novák M, Filip J, Gadas P, Galiová MV (2014) Iron + magnesium-bearing beryl from granitic pegmatites: an EMPA, LA-ICP-MS, Mössbauer spectroscopy, and powder XRD study. Canad Mineral 52: 271-284

Schaller WT, Stevens RE, Jahns RH (1962) An unusual beryl from Arizona. Amer Miner 47: 672-699

SHANNON RD (1976) Revised effective ionic radii and systematic studies of interatomic distances in halides and chalcogenides. Acta Crystallogr A32: 751-767

Simmons WB (2007) Gem-bearing pegmatites. In: GroAT LA (ed) Geology of Gem Deposits. Mineralogical Association of Canada, Short Courses 37: 169-206

Turner D, Groat LA, Hart CJR, Mortensen JK, Linnen RL, GiUliani G, Wengzynowski W (2007) Mineralogical and geochemical study of the True Blue aquamarine showing, southern Yukon. Canad Mineral 45: 202-227
UHER P (1991) Be-Nb-Ta granitic pegmatites - a new type of rare-element mineralization in the Western Carpathians. Geol Carpath 42: 331-339

Uher P (1992) Rare-element Be-Nb-Ta Mineralization in Granitic Pegmatites of the Western Carpathians. Unpublished PhD Thesis, Comenius University, Bratislava, pp 1-180 (in Slovak)

Uher P (1994) The Variscan West-Carpathian granitic pegmatites: mineralogy, petrogenesis and relationship to pegmatite populations in the Eastern Alps and Romanian Carpathians. Geol Carpath 45: 313-318

Uher P, BenKo P (1997) Beryl-columbite pegmatite on the Dúbrava deposit in Nízke Tatry Mts. Natura Carpatica 38: 181-184 (in Slovak)

Uher P, Broska I (1995) Pegmatites in two suites of Variscan orogenic rocks (Western Carpathians, Slovakia). Mineral Petrol 55: 27-36

UHER P, Chudík P, BAČík P, VACUlovič T, GALiová M (2010) Beryl composition and evolution trends: an example from granitic pegmatites of the beryl-columbite subtype, Western Carpathians, Slovakia. J Geosci 55: 69-80

Viana RR, Jordt-Evangelista H, da Costa GM, Stern WN (2002) Characterization of beryl (aquamarine variety) from pegmatites of Minas Gerais, Brazil. Phys Chem Miner 29: 668-679

Wang RC, Che XD, Zhang WL, Zhang AC, Zhang H (2009) Geochemical evolution and late re-equilibration of Na-Cs-rich beryl from the Koktokay \#3 pegmatite (Altai, NW China). Eur J Mineral 21: 795-809

Wood DL, NASSAU K (1968) The characterization of beryl and emerald by visible and infrared absorption spectroscopy. Amer Miner 53: 777-800 